\title{
AutoficÇÃo FEMINinA: A MULHER NUA DiANTE DO ESPELHO
}

Eurídice Figueiredo ${ }^{1}$

\section{RESUMO:}

Examinando o campo literário em língua francesa pode-se perceber que, dentre as várias tendências do romance contemporâneo, destaca-se a proliferação de narrativas de escritoras que relatam sua vida sexual, colocando-se como protagonistas, com seu nome próprio (ou pseudônimos). Trata-se de um novo gênero, a autoficção, que embaralha as categorias de autobiografia e ficção. Neste texto vou tratar de duas escritoras: Christine Angot (França) e Marie-Sissi Labrèche (Quebec), abordando de um lado a questão da autoficção, de outro a questão do tratamento dado à escrita da sexualidade, com suas interdições, transgressões e profanações.

PALAVRAS-CHAVE: literatura francesa; literatura do Quebec; autoficção; erotismo; loucura; profanação.

\section{ABSTRACT:}

In the field of contemporary literature written in French one can perceive that, among other trends of the novel, it is quite proeminent the proliferation of narratives produced by female writers who narrate their sexual life, occupying the role of protagonists, bearing their own names (or pseudonyms). It is a new genre, self fiction, that blurs the categories of autobiography and fiction. This text will deal with two writers: Christine Angot (France) and Marie-Sissi Labrèche (Quebec), tackling the issue of self fiction as well as the approach given to the writing of sexuality that includes interdictions, transgressions and profanations.

KEYWORDS: French Literature; Literature from Quebec; self fiction; eroticism; madness; profanation

\section{Autoficção: definição}

Un être humain sensé peut-il avoir avec lui-même une autre relation que spéculaire? (Catherine Millet)

A maneira de construir e encarar as categorias de autobiografia e ficção sofreu grandes transformações nos últimos 30 anos, e hoje as fronteiras entre elas se desvaneceram. A autoficção é um gênero que embaralha as categorias de autobiografia e ficção de maneira paradoxal ao juntar, numa mesma palavra, duas formas de escrita que, em princípio, deveriam se excluir. Apesar de todos saberem que o escritor sempre se inspirou (também) em sua própria vida, a ficção foi o caminho trilhado pelo romance ocidental para se firmar ao longo da História. Como o romance autobiográfico foi, tradicionalmente, considerado um filho bastardo, um híbrido, que quase sempre mereceu o desprezo da crítica, a autoficção acabou por ocupar esse lugar, embora com formatos inovadores. A contemporaneidade assiste, assim, ao surgimento de novos tipos de escritas de si, descentradas, fragmentadas, com sujeitos instáveis que dizem "eu” sem que se saiba exatamente a qual instância enunciativa ele corresponde. Para escrever uma autobiografia, segundo Mikhail Bakhtin, o escritor deve tornar-se outro em relação a si mesmo, olhar-se com os olhos de um outro (2003, p. 13) pois o “acontecimento estético, para se realizar, necessita de dois participantes, pressupõe duas consciências que não coincidem” (2003, p. 20). Pelo tratamento do tema do duplo, do jogo especular, do espelho, tematiza-se a duplicidade do escritor que se expõe como se a ficção fosse parte de sua vida.

\footnotetext{
${ }^{1}$ Doutora pela UFRJ (1988), Professora da Universidade Federal Fluminense, Pesquisadora do CNPq. E-mail: euridice@bighost.com.br
} 
A autoficção é um gênero que foi criado por Serge Doubrovsky (1977). Sentindo-se desafiado por Philippe Lejeune que, no livro Le pacte autobiographique (1975, p. 31), indagava se seria possível haver um romance com o nome próprio do autor, já que nenhum lhe vinha ao espírito, Doubrovsky decidiu escrever um romance sobre si próprio. Assim, ele criou o neologismo de autofiction para qualificar seu livro Fils, assim definido na quarta capa (nas edições mais recentes, o texto tornou-se parte de um prefácio):

Autobiografia? Não, isto é um privilégio reservado aos importantes deste mundo, no crepúsculo de suas vidas, e em belo estilo. Ficção, de acontecimentos e fatos estritamente reais; se se quiser, autoficção, por ter confiado a linguagem de uma aventura à aventura da linguagem, fora da sabedoria e fora da sintaxe do romance, tradicional ou novo. Encontro, fios de palavras, aliterações, assonâncias, dissonâncias, escrita de antes ou de depois da literatura, concreta, como se diz em música. Ou ainda: autofricção, pacientemente onanista, que espera agora compartilhar seu prazer (DOUBROVSKY, 1977, p. 10) ${ }^{2}$.

Doubrovsky lembra que, quando se escreve autobiografia, tenta-se contar toda sua história, desde as origens. Já na autoficção pode-se recortar a história em fases diferentes, dando uma intensidade narrativa própria do romance. Vincent Colonna considera que o uso do neologismo autoficção deve-se restringir ao caso dos autores que inventam uma personalidade e uma existência literária (COLONNA, 2004, p. 198).

A autoficção, enquanto ficcionalização de fatos e acontecimentos absolutamente reais, é uma palavra que hoje consta dos dicionários Larousse e Robert (com acepções contraditórias) e que entrou na moda, sendo usada agora de maneira indiscriminada, segundo o próprio Doubrovsky. Philippe Gasparini fala de "deriva semântica" e de "efeito de moda" (GASPARINI, 2004, p. 310). Vincent Colonna diz que não se trata de "um gênero mas talvez de uma nebulosa de práticas aparentadas", ou ainda "uma mitomania literária” (COLONNA, 2004, p. 11-13). Philippe Lejeune também critica a banalização de seu emprego, dizendo que ela se tornou um verdadeiro pano de chão, uma vassoura que recolhe tudo (LEJEUNE, 2005, p. 170). Colocando os pingos nos is, seu criador afirma que, para que haja autoficção, é preciso que os nomes de autor, narrador e personagem sejam idênticos, ou seja, o autor deve assumir esse risco (apud VILAIN, 2005, p. 205). Além disto, é preciso que o texto seja lido como romance e não como recapitulação histórica (apud VILAIN, 2005, p. 209).

A autoficção, tal como concebida por Doubrovsky, seria “uma variante 'pós-moderna' da autobiografia na medida em que ela não acredita mais numa verdade literal, numa referência indubitável, num discurso histórico coerente e se sabe reconstrução arbitrária e literária de fragmentos esparsos de memória” (apud VILAIN, 2005, p. 212). Outro aspecto importante seria a questão da linguagem: em seus textos os espaços brancos interrompem a continuidade discursiva, o que demonstra que a sintaxe tradicional não é mais possível. Assim, Doubrovsky considera que quem faz autoficção hoje não narra simplesmente o desenrolar de fatos, preferindo antes deformá-los, reformá-los através de artifícios (apud VILAIN, 2005, p. 216).

\footnotetext{
${ }^{2}$ Sempre que houver citação em português de livros cuja referência bibliográfica esteja em francês, trata-se de tradução minha.
} 
Como observa Régine Robin, na "busca de uma identidade pluralizada pelos fantasmas de autoengendramento, existe uma zona limite, uma margem em que a passagem ao ato tende a apagar as fronteiras entre o mundo fantasmático do autor e o real sociobiográfico" (1997, p. 16). A autoficção toma a forma disseminada de Proteu, que é o desejo de "ocupar todos os lugares", desempenhando todos os papéis:

Representar todos os outros que estão em mim, me transformar em outro, dar livre curso a todo processo de virar outro, virar seu próprio ser de ficção ou, mais exatamente, esforçar-se para experimentar no texto a ficção da identidade; tantas tentações fortes, quase a nosso alcance e que saem atualmente do domínio da ficção (ROBIN, 1997, p. 16).

Régine Robin afirma que a autoficção é ficção, o sujeito narrado é um sujeito fictício justamente porque é narrado, ou seja, é um ser de linguagem; assim, não pode haver adequação entre o autor, o narrador e o personagem, entre o sujeito do enunciado e o sujeito da enunciação, entre o sujeito em princípio pleno (o escritor) e o sujeito dividido, disperso, disseminado, da escrita. A narrativa contemporânea esforça-se em embaralhar as marcas e os sinais, em refinar os efeitos de polifonia através de vários procedimentos de escrita, que vão do duplo à ventriloquia, passando pelo tratamento de diferentes vozes (ROBIN, 1997, p. 17).

Philippe Gasparini define assim a autoficção:

Texto autobiográfico e literário que apresenta numerosos traços de oralidade, de inovação formal, de complexidade narrativa, de fragmentação, de alteridade, de disparatado e de auto-comentário, os quais tendem a problematizar a relação entre a escrita e a experiência (GASPARINI, 2008, p. 311).

Ele considera que a autoficção (que ele preferiria chamar de auto-narração), além de ser uma categoria literária, constitui ao mesmo tempo um sintoma, um produto e um ressonador da época já que a "cultura de si” , para usar a expressão de Michel Foucault, substituiu as utopias de um futuro melhor, o hedonismo substituiu o militantismo e a escrita de si entrou no lugar dos mitos escatológicos (GASPARINI, 2008, p. 322-325).

\section{Narrativa feminina da sexualidade: preâmbulo}

A mulher nas mãos daquele que a ataca é despossuída de seu ser. Ela perde, com seu pudor, esta firme barreira que, separando-a do outro, tornava-a impenetrável: ela se abre bruscamente à violência do jogo sexual deflagrado nos órgãos da reprodução, à violência impessoal que, vinda de fora, a ultrapassa. (Georges Bataille)

A temática da sexualidade, sobretudo quando escrita por mulheres, ainda provoca escândalo embora o choque de hoje esteja longe daquele provocado pela publicação de Histoire d'O., de Pauline Réage, em 1954. É bom lembrar que Pauline Réage foi o pseudônimo adotado por Dominique Aury (que já era um pseudônimo de Anne Desclos) para publicar esse único livro. Com o nome Dominique Aury, ela publicou Anthologie de la poésie religieuse française (1943), Lecture pour tous (1956), além de ter traduzido Evelyn Waugh, Scott Fitzgerald, entre outros. Amante de Jean Paulhan, o diretor da NRF 
(Nouvelle Revue Française), da qual ela era a secretária geral, Dominique Aury criou uma narrativa sadomasoquista em que a mulher apaixonada é de uma submissão total ao homem. Ela não visava à publicação; tratava-se de um jogo erótico confidencial. No entanto, Paulhan decidiu publicar o livro, seguindo uma tradição francesa de literatura libertina (além do Marquês de Sade, pode-se mencionar $A s$ ligações perigosas, de Choderlos de Laclos). As editoras Gallimard e Deux Rives recusaram, apesar do prefácio de Jean Paulhan, intelectual muito respeitado na época. A pequena editora Jean-Jacques Pauvert aceitou o risco. A justiça tentou processar a autora, mas não obteve de Paulhan a revelação do segredo. Houve toda uma querela sobre a autoria (pensaram que Jean Paulhan era o autor), sobre pornografia, sobre imoralidade. Em 1975 o livro foi transposto para o cinema sob a direção de Just Jaeckin. Em 1994, aos 87 anos, Aury reconheceu, em entrevista à New Yorker, que ela era a autora do livro. Ao longo desse caminho tortuoso, foram vendidos 850.000 exemplares (GARCIN, 2002). Muito inspirado na obra do Marquês de Sade, o romance é puramente ficcional e não corresponde ao modelo de autoficção de que se tratará nesse artigo. A menção a esse livro deve-se à importância histórica que ele teve no gênero de escrita feminina da sexualidade ao longo do século XX.

O fato de Histoire d'O ter saído em edição de bolso (na coleção Le livre de poche) em 2002 aponta para as mudanças ocorridas tanto em relação à percepção da pornografia e do erotismo - e das sutis diferenças que haveria entre os dois - quanto em relação à questão da autoria feminina. Não se admitia que uma mulher pudesse escrever aquele livro, afirmava Albert Camus (apud GARCIN, 2002). Desde o final dos anos 1990 surgiram muitas narrativas autoficcionais escritas por mulheres: de um lado, autoras neuróticas, que tratam o lado obscuro e dramático da subjugação do corpo da mulher pelo homem, como a francesa Christine Angot (nascida em 1959), as quebequenses Pauline Gélinas (nascida em 1962), Nelly Arcan (1975-2009) e Marie-Sissi Labrèche (nascida em 1969); de outro lado, escritoras performáticas e midiáticas em que se destaca a francesa Catherine Millet (nascida em 1948).

Como se depreende das datas de nascimento, predominam mulheres jovens. Catherine Millet, a mais velha do grupo, fundadora e diretora da Art Press, influente revista de arte na França, causou polêmica ao lançar La vie sexuelle de Catherine $M$. em 2001, no qual relata sua intensa vida sexual com inúmeros parceiros, conhecidos e desconhecidos, nos lugares mais variados, inclusive em locais públicos como o Bois de Boulogne, o Bois de Vincennes, o estacionamento da Porte Saint-Cloud. Ao contrário de Histoire d'O, cuja linguagem é pudica, sem designar os órgãos sexuais pelos termos comuns, Millet descreve as cenas de sexo de tal maneira que se poderia considerar sua obra no limite da pornografia embora ela afirme no prefácio que seu livro não mexe com o desejo do leitor porque ela não emprega vocabulário obsceno (MILLET, 2002, p. V). Na capa do livro, uma foto dela nua; seu marido, o escritor Jacques Henric, publicou o livro La légende de Catherine M., no mesmo ano (2001), com mais fotos de Catherine M. nua.

Num registro diferente, há os relatos de profissionais do sexo. No Brasil o caso mais notório foi o de Bruna Surfistinha, pseudônimo de Raquel Pacheco (nascida em 1984) que, depois de fazer sucesso escrevendo em blog, lançou em $2005 O$ doce veneno do escorpião. O sucesso se traduziu pela venda de 250 mil exemplares e pela adaptação que está sendo feita para o cinema. Ela publicou posteriormente $O$ que aprendi com Bruna Surfistinha (2005) e Na cama com Bruna Surfistinha (2007), que tiveram pouco êxito se comparados com o primeiro. No Quebec, Nelly Arcan contou sua vida de garota de programa enquanto 
fazia o curso de Letras na UQAM (Université du Quebec à Montréal), onde concluiu Graduação e Mestrado. Ela afirma ter escrito o livro Putain (2002) com ódio; tinha raiva e nojo dos homens com os quais fazia sexo. Obcecada por beleza e juventude, preocupada em ser vista como escritora e não como prostituta, obteve certo reconhecimento de crítica e público, tendo sido finalista dos prêmios Médicis e Fémina na França. Suicidou-se em 2009, aos 34 anos de idade. Neste texto vou tratar de duas escritoras: a francesa Christine Angot e a quebequense Marie-Sissi Labrèche.

\section{Christine Angot}

Ma vie n'est devenue qu'écriture maintenant. Il n'y a plus que ça.

(Christine Angot)

Em L'inceste (1999 a), que lhe deu fama, e L'usage de la vie (1999 b), a autora se desvela, expõe seu corpo e sua sexualidade. Apesar de usar palavras populares (os mais moralistas diriam vulgares) e referir-se aos atos sexuais, Angot não descreve o prazer, mas antes, os problemas ligados ao sexo e aos relacionamentos afetivos. A história de sua vida é marcada por uma mudança que se deu quando, aos 14 anos, conheceu o pai - que só então a reconheceu e lhe deu o nome Angot ${ }^{3}$ - e foi seduzida por ele. Não há propriamente estupro, mas sedução porque ela poderia ter denunciado o fato à mãe e ter-se recusado a passar finais de semana com o pai. O incesto teria acontecido dos 14 aos 16 anos, quando seu então namorado Marc teria enfrentado a figura do pai, fazendo cessar o relacionamento interdito. O que ela narra, mas não explica, é a razão de ela ter voltado aos braços do pai quando já era casada com Claude, seu companheiro e pai de sua filha Léonore. De acordo com seus textos, tudo só teria acabado quando ela tinha 28 anos. A definição de incesto que ela dá no livro, citando o Dictionnaire de la psychanalyse de Elizabeth Roudinesco e Michel Plon é:

Chama-se incesto uma relação sexual sem constrangimento nem estupro entre consanguíneos [...] é frequentemente ocultado e sentido como uma tragédia pelos que se abandonam a ele [...]. O ato é reprovado pela opinião e é sempre vivido como uma tragédia originária da desrazão ou que conduz à loucura ou ao suicídio (ANGOT, 1999 a, p. 131. Grifos da autora).

A escritora usa os nomes verdadeiros dos membros de sua família, e de forma um pouco abusiva, do nome de sua filha - que era, então, uma criança - e que dá título a um de seus livros, Léonore, toujours (1994). Em L'usage de la vie ela tematiza essa questão através do que teria sido um relatório de leitura de uma editora, escrito por um tal de Laclave (a chave, em espanhol):

Léonore e Interview são gritos de dor. Trata-se por isto de obras literárias? Christine Angot não toma nenhuma distância em relação às relações perversas que ela descreve. Não falo do incesto, mas das relações entre a autora, seu companheiro Claude, e a filha deles. Apesar da admiração que tenho por ela, sou hostil. A utilização de Léonore (que, lembremos, existe) na construção de um universo mórbido e carcerário, me dá medo. Nem falemos de Claude, que aceita ver sua vida íntima

\footnotetext{
${ }^{3}$ Até os 14 anos ela usava o sobrenome da mãe e se chamava Christine Schwartz.
} 
exposta em público de forma sinistra e miserável. Deleite patológico do sofrimento (ANGOT, 1999 b, p. 30).

Ela encena essa questão do conflito público-privado em L'inceste através da voz de sua advogada, que a proíbe de colocar os nomes verdadeiros de seus familiares assim como os de sua amante, MarieChristine Adrey, e da atriz Nadine Casta, nomes que são repetidos à exaustão no livro, ou seja, trata-se de uma simples encenação, já que ela não acata a interdição.

Este manuscrito apresenta de maneira recorrente um problema ligado à divulgação da vida privada dos próximos da autora, sobretudo de sua filha Léonore, menor, de seu ex-cônjuge, Claude, de seu pai [...]. Outras pessoas veem também a intimidade de sua vida privada exposta escancaradamente, em detalhes, sobretudo Marie-Christine Adrey, amante da autora e 'personagem' principal da obra, a atriz Nadine Casta, etc (ANGOT, 1999 A, p. 41)

Há uma oscilação entre realidade e ficção, o que ela escreve não deve ser confundido com a verdade, tudo é um jogo autoficcional em que a escritora-narradora-protagonista ficcionaliza sua vida e "a única coisa autobiográfica aqui, atenção, é a escrita”, afirma ela no mesmo livro, algumas páginas depois. E continua: "Meu personagem e eu estamos colados a este lugar. Fora isto todo o resto é literatura. Os verdadeiros nomes são para que o muro se afine e ao mesmo tempo se espesse" (ANGOT, 1999 B, p. 40). O pacto pretensamente estabelecido com o leitor se embaralha, o leitor não tem elementos que lhe permitam verificar se essas pessoas realmente existem ou se são simples personagens ficcionais, que aparecem como sendo verdadeiras.

A homossexualidade mostrada em L'inceste, principalmente na primeira parte, No man's land, aparece sob o prisma da neurose, da insatisfação, da angústia, da recusa. Não se vê prazer na obra de Angot, ela apela antes para a loucura, o comportamento obsessivo, patológico, inclusive nos romances não autoficcionais. Ela insiste que precisa procurar um psicanalista, às vezes menciona a necessidade de se internar numa clínica. A homossexualidade está ligada à ideia de incesto, de união fusional, em que até mesmo sua filha entra, confundindo os nomes de Léonore et Marie-Christine.

O nome da amante, Marie-Christine, é a reduplicação do seu, ou seja, trata-se de uma gêmea, um clone, um duplo. Aliás, ela menciona que a mãe queria chamá-la de Marie-Christine, mas o pai não quis o Marie. Citando o Dictionnaire de la Psychanalyse de Elizabeth Roudinesco e Michel Plon, ela escreve que a paranoia se define como uma defesa contra a homossexualidade (ANGOT, 1999 A, p. 133). O que se vê no livro é a coexistência de homossexualidade e paranoia.

A escrita funciona como um muro que a protege da loucura; sua obra funciona como o espaço privilegiado para a encenação de seu comportamento delirante, num estilo extremamente repetitivo, alucinatório, que remete para uma mente obsessiva. 


\section{Marie-Sissi Labrèche}

Je suis borderline. J'ai un problème de limite.

(Marie-Sissi Labrèche).

O romance de Marie-Sissi Labrèche, Borderline, publicado em $2000^{4}$, é autorreferencial e encena a vida neurótica de sua protagonista. A personagem se chama Sissi como ela e escreve na primeira pessoa, expondo sua vida sexual e amorosa. Ela, que fez sua dissertação de Mestrado na UQAM sobre autoficção, assim se explica:

A autoficção é um jogo com o leitor. O autobiógrafo quer contar a verdade enquanto o escritor autoficcional conta alguma, mas não toda. Às vezes, ele só empresta seu nome ao personagem. [...] Todos os romances têm uma parte de autoficção. Todos se inspiram do que se vive e do que se faz ao escrever. Só que na autoficção é explicitado. A identidade do nome está ali (LABRÈCHE, 2009, Entrevue).

Borderline alterna os capítulos que se passam no presente da enunciação e os diferentes passados: da idade de 11 anos à idade de 5 anos, remontando sempre para trás quando se trata do passado, e avançando nos capítulos que tratam do presente, de 23 a 26 anos. Como o título indica, trata-se de uma jovem borderline, ou seja, alguém que não conhece as fronteiras, o que é facilmente compreensível já que a mãe era louca e se suicidou quando a menina tinha 11 anos e que a avó, que a criou, não era muito normal tampouco. No prólogo, a avó a ameaça não com personagens da mitologia infantil como o Bicho Papão, por exemplo, mas com serial killer, estuprador, traficante de escravas brancas, em suma, elementos de uma mitologia urbana e moderna veiculada pela televisão (LABRÈCHE, 2003, p. 11).

Essa família disfuncional só pode engendrar uma borderline. No capítulo 1, intitulado “Cendrillon”, a cena se passa em um hotel. O ato sexual descrito é degradante, pois a protagonista coloca-se numa situação de auto-punição, ao aceitar fazer algo que lhe provoca repulsa. Ela está de pernas abertas, com as mãos sobre o busto, imóvel, como se estivesse morta, num caixão (LABRĖCHE, 2003, p. 13). Ela poderia fechar as pernas, mas não o faz porque se compraz nessa pose de autoflagelação e de autocomiseração. Há em sua atitude impudente, uma certa provocação, comparável à das mulheres analisadas por Giorgio Agamben, as quais exageram a indecência das fotos pornográficas pelo olhar direto para a câmera, exibindo sua consciência de estarem expostas (AGAMBEN, 2007, p. 78).

A protagonista de Marie-Sissi Labrèche sofre da ausência de pai — ele é apenas mencionado —, vivendo entre duas mulheres bastante desequilibradas e patéticas, a mãe e a avó. Construída pelo desejo incestuoso pela mãe e pela separação brutal dela, o borderline, segundo Kristeva, sofre de uma carência da função paterna, o que provoca o sentimento ao mesmo tempo de clausura e vazio.

O eu lança-se então numa corrida às identificações reparadoras do narcisismo, identificações que o sujeito sentirá como in-significantes, 'vazias', 'nulas', 'desvitalizadas', 'marionetes'. Um castelo vazio habitado por fantasmas nada engraçados... 'impotente’ por fora, 'impossível' por dentro (KRISTEVA, 1980, p. 60).

\footnotetext{
${ }^{4}$ Eu uso a edição de 2003 de Borderline. Além deste, ele escreveu La brèche em 2002 e La lune dans un HLM em 2006. Neste texto vou tratar só de Borderline apesar de me referir, eventualmente, aos outros.
} 
O alcoolismo faz parte desse comportamento borderline: ultrapassando todos os limites, ela se exibe de modo espetacular, torna-se inconveniente. Em suas festas de aniversário, ela se embriaga a fim de poder esquecer seu comportamento desestruturado, sua angústia, seu sentimento de culpabilidade. Ela se expõe, tira a roupa, faz besteira, acaba na cama com qualquer um, torna-se abjeta, goza talvez nesse/desse pathos. Ela representa o papel de mulher-objeto-do-desejo dos homens. O exibicionismo da protagonista faz parte do jogo espetacularização/voyeurismo que caracteriza a sociedade contemporânea. Assim, a imagem da jovem loira e bela seduz e causa repulsa ao mesmo tempo, os homens têm medo de seu excesso e de suas transgressões. Ela busca desenfreadamente preencher o seu vazio.

Um dos aspectos mais visíveis de suas crises é o desdobramento de personalidade, traço esquizoide que começou muito cedo, quando ela teve de chamar a emergência do hospital após o suicídio da sua mãe. "Não sei como fiz. Não me lembro de nada. Na verdade, acho que foi outra menina que fez por mim. Uma outra menina loira como eu que me sorriu e tomou minha mão para discar o número" (LABRĖCHE, 2003, p. 31). Esse acontecimento traumático provoca pesadelos de noite e, ao despertar, angústia. Como ela tem dificuldades em suportar a realidade, ela se desliga e se vê vivendo do exterior (LABRĖCHE, 2003, p. 37). Ver-se em um filme, ver-se no espelho ou ver um duplo são as formas do desdobramento da personalidade que aparecem no livro.

O espelho, como foi demonstrado pela psicanálise, é uma fase fundadora do processo de individuação. No caso em questão, o espelho que se estilhaça no fim do romance significa o esfacelamento do eu, a perda e a desintegração (LABRÈCHE, 2003, p. 110). E à medida que ela faz uma anamnese, voltando cada vez mais longe no passado, o leitor se dá conta que a doença mental começara muito cedo: o suicídio da mãe, as ameaças da avó de colocá-la numa família adotiva que iria maltratá-la, em suma, sua vida é uma coleção de desventuras. Ela faz confidências a uma amiga, ela compartilha suas angústias, provoca sofrimento em outrem, sua amiga chora, se preocupa com ela (LABRÈCHE, 2003, p. 40). Mas mesmo antes, aos 8 anos, ela faz um desenho que choca a professora: ela desenha dois olhos azuis tristes, os olhos de sua mãe louca, toda a classe fica traumatizada. Aos 7 anos, sua mãe está no hospital e ela é uma criança hiperativa, agitada, muito criativa apesar de todos os problemas familiares; aos 5 anos, ela passa horas diante da televisão. E aí se chega talvez à causa fundadora de sua culpabilidade: a avó forçou-a a afirmar que seu padrasto abusara dela a fim de poder provocar a separação do casal. Diante do fato consumado, a menina se sente culpada, um verdadeiro Judas. A última frase do capítulo é: "A partir de agora, meus jogos não terão fronteiras e estarei em guerra contra a humanidade mas sobretudo contra mim mesma" (LABRÈCHE, 2003, p. 135). Borderline termina com uma crise na qual ela quebra o espelho, fica com cicatrizes, passa a ter acompanhamento de uma psicóloga, os espelhos são retirados.

Nos dois livros subsequentes a protagonista tem outros nomes, Emilie-Kiki em La brèche e Léa em La lune dans un HLM, o que desvirtua o caráter de autoficção, já que a principal exigência, para Doubrovsky, é que o personagem tenha o mesmo nome do autor. Apesar disso, deve-se ressaltar que o título do segundo romance corresponde ao seu sobrenome e que ela mescla alguma ficção aos dados de sua própria biografia. 


\title{
Interdito, transgressão, profanação
}

\begin{abstract}
Na medida de sua atração, uma mulher serve de alvo ao desejo dos homens. A menos que ela se esquive inteiramente, por um parti pris de castidade, a questão é, em princípio, saber a que preço, em que condições, ela cederá. A prostituição propriamente dita não introduz senão a prática da venalidade (Georges Bataille).
\end{abstract}

Agamben retoma o conceito de "valor de exposição", criado por Walter Benjamin, um terceiro termo além dos dois criados por Marx: "valor de uso" e "valor de troca". "Nada poderia caracterizar melhor a nova condição dos objetos e até mesmo do corpo humano na idade do capitalismo realizado do que esse conceito" (AGAMBEN, 2007, p. 77). Assim, vê-se na autoficção a exposição pública da vida íntima e privada, notadamente do corpo da mulher, o que leva Philippe Vilain (2005) a falar de "extimidade", ou seja, o que deveria permanecer reservado (prefixo IN) é exposto (prefixo EX). Há um inegável narcisismo nesta exibição da vida sexual e até mesmo quando se trata de prostituição: aquilo que deveria (poderia) permanecer secreto por pudor ou por provocar vergonha, é impresso e divulgado. Esse exibicionismo está muito presente em nossa sociedade, sobretudo na mídia: nos blogs e sites da Internet, nos reality shows da televisão e nas revistas de fofocas, na perseguição dos paparazzi em busca de fotos sensacionalistas de celebridades. Como as fronteiras entre alta cultura e cultura de massa também se desvaneceram, a literatura produzida por essas autoras expõe biografemas (elementos biográficos) que teriam sido silenciados no passado e que podem parecer às vezes chocantes.

Ao analisar essas narrativas dois aspectos se imbricam: o espaço no qual se passam as cenas de sexo e a ideia de prostituição. De modo significativo, os personagens se encontram sobretudo em hotéis ou outros espaços públicos, esses "não-lugares", na expressão de Marc Augé, para o qual o "não-lugar" designa duas realidades complementares porém distintas: de um lado, seria o espaço constituído para certos fins (transporte, comércio, trânsito), e de outro, a relação que os indivíduos entretêm com esses espaços. Ao contrário do lugar antropológico, que cria um social orgânico, o não-lugar cria uma contratualidade solitária (AUGÉ,1992, p. 118-119).

A questão da prostituição é complexa porque, salvo Nelly Arcan (e Bruna Surfistinha), que assume ter exercido a profissão, nenhuma outra escritora o faz. No entanto, todas usam a palavra pute ou putain em algum momento. Como Marie-Sissi Labrèche serve de objeto sexual a um homem que ela não deseja, que, ao contrário, a enoja, ela se vê como puta, ela tem vergonha. A exposição de seu corpo é reiterada pela exploração impudica de seu sobrenome, Labrèche, que expõe a abertura de seu corpo de maneira obscena. Em L'inceste a amante da protagonista a chama de "putinha" (petite pute) duas vezes (ANGOT, 1999 a, p. 31). Usar palavras grosseiras é uma forma de rebaixamento porque são interditos; nomear os órgãos ou atos sexuais, chamar-se de puta, segundo Bataille, faz passar da transgressão à indiferença, o que põe num mesmo plano o profano e o mais sagrado (BATAILLE, 1987, p. 127) ou seja, cria um ato de profanação.

Sim! Sou uma puta! Mas não sou uma puta como você pensa. Não sou uma puta como nos programas de tevê ou na esquina da rua Champlain! Não faço isto por dinheiro, porra! Faço isto para me acalmar, porra! (LABRĖCHE, 2003, p. 14). 
Profanar, como lembra Giorgio Agamben, é entregar ao uso comum aquilo que era reservado aos deuses, ou seja, o sagrado. Pode-se pensar que um corpo violentado foi profanado quando a relação sexual não é fruto do desejo da mulher de juntar-se ao corpo do homem desejado e/ou amado. Embora na cena de abertura do romance Sissi não tenha sido estuprada, já que ela aceitou ir ao hotel com o gordo Eric, ela se sente morta porque aceitou desempenhar o papel tradicional de objeto do desejo de outrem. Essa passividade que leva a mulher a praticar o ato sexual para agradar o homem aparece também nas descrições de incesto de Christine Angot. "Na medida de sua atração, uma mulher serve de alvo ao desejo dos homens" (BATAILLE, 1987, p. 123). O fato de considerar que foi usada como uma prostituta dilacera Sissi, o que a leva a se descrever deitada na cama como se fosse uma morta em seu caixão, com as duas pernas bem abertas, emblema de sua abjeção: de mulher penetrada sem desejo e, portanto, sem prazer. Julia Kristeva afirma que as vítimas do abjeto são dóceis e consentem, fascinadas, em mergulhar na abjeção (KRISTEVA, 1980, p. 17).

Bataille distingue a prostituição sagrada da moderna prostituição: na primeira a vergonha pôde se tornar ritual enquanto, na moderna, a vergonha sentida pela prostituta se articula com o desprezo manifestado pelos outros, no ato de cometer a transgressão do interdito.

É pela vergonha, representada ou não, que uma mulher se harmoniza com o interdito que cria nela a humanidade. O momento é ultrapassado, mas trata-se de marcar então, pela vergonha, que o interdito não é esquecido, que a ultrapassagem acontece apesar do interdito, na consciência do interdito (BATAILLE, 1987, p. 125).

A doença mental e as crises de loucura como desdobramentos de problemas que têm origem na sexualidade são tematizadas pelas duas escritoras através do sentimento da vergonha. Segundo Sara Ahmed, ter vergonha é se sentir mal em relação a si mesmo diante dos outros, o que acarreta a autonegação. Esse sentimento de negação de si é considerado pelo sujeito como um signo de sua derrota diante dos outros (AHMED, 2007, p. 17). Assim a vergonha se assemelha à exposição — o outro viu o que eu fiz de mau e vergonhoso - mas ela implica também o desejo de esconder, o que requer que o sujeito se afaste dos outros. Ser visto em sua derrota é ser exposto à vergonha; ter testemunhas de sua vergonha é ainda mais vergonhoso (AHMED, 2007, p. 18). A individuação da vergonha que volta o eu contra e para si pode-se ligar à intercorporalidade e à sociabilidade das experiências da vergonha. A marginalização (apartness) do sujeito, que se intensifica pelo retorno do olhar, é sentida no momento de exposição diante dos outros, uma exposição que é ferida (AHMED, 2007, p. 19). A vergonha torna as personagens ao mesmo tempo indignas e incapazes de formar um casal de maneira harmoniosa; isso resulta sempre em frustração, em exposição a novas experiências de profanação de seu corpo, de vergonha e de abjeção.

\section{Conclusão: autoficção como escrita do duplo}

Doit-on admettre que réalité et fiction ne sont pas en relation d'opposition, mais d'interdépendance? Je vit dans un réel fictionné et se contente de dupliquer le récit de sa fiction vécue, à savoir, un univers préinscrit (Philippe Vilain). 
Um dos aspectos que revelam o caráter especular é o lesbianismo como expressão de um desdobramento narcísico, tanto em Angot quanto em Labrèche. Na primeira, a amante tem o mesmo nome que ela, na segunda, elas são parecidas, como uma irmã gêmea ou como um clone.

O corpo dela é como o meu. Nem acredito. Mesma cintura, mesmos seios, mesmos cabelos, mesmos olhos sorridentes. Será que eu toco em mim mesma? Estaria eu em plena crise narcísica? Estaria eu deitada sobre o espelho? Será que o espelho vai-se quebrar e eu vou me afogar? É doido mas de repente estou com medo (LABRÈCHE, 2003, p. 81).

Se a autoficção é, para Doubrovsky, "autofricção, pacientemente onanista, que espera agora compartilhar seu prazer" (1977, p. 10), a autoficção feminina parece querer compartilhar menos seu prazer - quase sempre ausente — e mais suas angústias. Em ambas as autoras a escrita serve de remédio ou proteção contra a doença mental. Angot afirma que a "escrita é um muro contra a loucura, tenho sorte em ser escritora, ter ao menos esta possibilidade” (ANGOT, 1999 b, p. 171). Ao encenar o seu duplo vivendo os conflitos existentes na exposição do corpo da mulher aos predadores masculinos, a autoficção feminina reflete mais uma vez os impasses existentes em relações desiguais que as mulheres têm com os homens em nossa sociedade. A diferença importante em relação ao passado é que agora são as mulheres que têm acesso à escrita e à publicação e que narram assim sua vida de intelectuais que devem fazer face à sua condição.

Desde Les confessions de J. J. Rousseau, o ego scriptor, o tornar-se escritor, o ato de se olhar escrever, firmou-se como um topos da autobiografia e gêneros correlatos. Assim, ao criar a personagem da escritora, que se desdobra em vários papéis, as autoras em questão encontraram a estratégia narrativa para se colocar em cena de maneira especular, já que elas se veem como uma outra que escreve. Segundo Philippe Vilain, a particularidade da imaginação autobiográfica reside em sua capacidade de desdobramento narcísico que permite ao sujeito inventar para si um duplo, ideal ou não, e tornar possível uma forma de autoficcionalização (VILAIN, 2005, p. 119).

É graças à possibilidade de criar um duplo de si que essas escritoras podem expor-se, com seu próprio nome, nessas formas de autoficção, desvelando assuntos tabus como incesto e prostituição, ou ainda, explorando temas como lesbianismo, desdobramento esquizoide ou paranoico, porque a autoficção não tem compromisso com a verdade, ela é uma ficção que se inspira e joga, livremente, com os biografemas. Ao mesmo tempo, deve-se destacar que essa escrita feminina sobre a sexualidade se propõe a fazer uma releitura do papel arcaico da mulher, que é a de ser objeto do desejo do homem e, por isto, às vezes, faz alusão, por exemplo, aos grandes mitos da feminilidade criados pelos contos de fadas como Cinderela, a Bela Adormecida, Chapeuzinho Vermelho. O que faz a diferença é que, numa sociedade permissiva que se compraz no binômio exibicionismo-voyeurismo, as escritoras ficcionalizam suas próprias vidas, exibindo uma sexualidade que, longe de ser bem resolvida e prazerosa, parece ser ainda bastante problemática. 


\section{Referências bibliográficas}

AGAMBEN, Giorgio. "Elogio da profanação". In: Profanações. Tradução e apresentação Selvino J. Assmann. São Paulo: Boitempo, 2007. p. 65-80.

AHMED, Sara. "The Politics of Bad Feeling". In: KAPLAN, Ann, SCHECKEL, Susan (Edit). Boundaries of Affect. Ethnicity and Emotion. The Occasional Papers of the Humanities Institute at Stony Brook.n. 3, State University of Stony Brook, 2007.

ANGOT, Christine. L'inceste. Paris: Stock, 1999 a. L'usage de la vie. Paris: Mille et une nuits, 1999 b.

AUGÉ, Marc. Non-lieux. Introduction à une anthropologie de la surmodernité. Paris: Seuil, 1992.

BAKHTIN, Mikhail. Estética da criação verbal. São Paulo: Martins Fontes, 2003.

BATAILLE, Georges. O erotismo. Porto Alegre: L\&PM, 1987.

COLONNA, Vincent. Autofictions \&autres mythomanies littéraires. Auch: Tristram, 2004.

DOUBROVSKY, Serge. Fils. Paris:Galilée, 1977.

GARCIN, Jérôme. Histoire d'O. Le Nouvel Observateur. Semaine du Jeudi 8 Août 2002. n. 1970 - Livres.

Disponível em: <http://www.arlindo.correia.com/021202.html>. Acesso em 20 jan. 2010.

GASPARINI, Philippe. Autofiction. Paris: Seuil, 2008. Est-il je? Roman autobiographique et autofiction. Paris: Seuil, 2004.

KRISTEVA, Julia. Les pouvoirs de l'horreur. Essai sur l'abjection. Paris: Seuil, 1980.

LABRÈCHE, Marie-Sissi. Borderline. Montréal: Boréal, 2003. La brèche. Montréal: Boréal, 2008.

La lune dans un HLM. Montréal: Boréal, 2006.

"Sortir de soi". Entrevue à Marc Cassivi. 10 février 2009. Disponível em: < http:/ /www.cyberpresse.ca/arts/livres/200902/10/01-825779-marie-sissi-labreche-sortir-desoi.php >. Acesso em: 20 jan. 2010

LEJEUNE, Philippe. Le pacte autobiographique. Paris: Seuil, 1975. .Signes de vie. Le pacte autobiographique 2. Paris: Seuil, 2005.

MILLET, Catherine. La vie sexuelle de Catherine M. Précédé de Pourquoi et comment. Paris: Seuil, 2001 (2002 pour la préface).

RÉAGE, Pauline. Histoire d'O. Edition revue et corrigée précédé par Le bonheur dans l'esclavage par Jean Paulhan. Paris: Jean-Pacques Pauvert, 1954-1972.

ROBIN, Régine. Le Golem de l'écriture. De l'autofiction au Cybersoi. Montréal: XYZ, 1997.

VILAIN, Philippe. Défense de Narcisse. Paris: Grasset, 2005.

Artigo recebido em: $31 / 01 / 2010$

Artigo aprovado em: 20/02/2010

Referência eletrônica: FIGUEIREDO, Eurídice. Autoficção feminina: a mulher nua diante do espelho, Revista Criação \& Crítica, n. 4, p. 91-102, 2010. Disponível em:

<http://www.fflch.usp.br/dlm/criacaoecritica/dmdocuments/08CC_N4_EFigueiredo.pdf> 